\title{
Government extension, agroecology, and sustainable food systems in Belize milpa farming communities: A socio-ecological systems approach
}

\author{
Kristin A. Drexler* \\ American Public University System
}

Submitted June 2, 2019 / Revised September 13, October 9, and October 10, 2019 / Accepted October 10, 2019 /

Published online March 16, 2020

Citation: Drexler, K. A. (2020). Government extension, agroecology, and sustainable food systems in Belize

milpa farming communities: A socio-ecological systems approach. Journal of Agriculture, Food Systems, and

Community Development, 9(3), 85-97. https://doi.org/10.5304/jafscd.2020.093.001

Copyright (C) 2020 by the Author. Published by the Lyson Center for Civic Agriculture and Food Systems. Open access under CC-BY license.

\begin{abstract}
The sustainability of milpa agriculture, a traditional Mayan farming system in southern Belize, is uncertain. For centuries, the milpa has been a sustainable agriculture system. The slash-and-burn aspect of milpa farming, however, has become less reliable and less sustainable over the last 50 years due to several factors, including forest loss, climate change, population growth, and other factors. The traditional milpa practices of slash-and-mulch and soil nutrient enrichment (nutrient cycling) are agroecological practices that produce food in a more sustainable way. Agriculture extension, a government service in Belize, can promote additional agroecological practices to address food and liveli-
\end{abstract}

\footnotetext{
* Kristin A. Drexler, Ph.D., Assistant Professor, Space Studies \& Earth Sciences, School of Science, Technology, Engineering and Math (STEM), American Public University System; 111 W. Congress Street, Charles Town, WV 25414 USA; kristin.drexler@mycampus.apus.edu
}

hood insecurities in milpa communities. This study examines perceptions of these practices from milpa farmers and agricultural extension officers in Belize using a socio-ecological systems (SES) framework. SES considers multidisciplinary linkages, including social, economic, environmental, cultural, and other factors in the agroecological system. The study finds several of these SES linkages between agroecological practices - specifically slash-andmulch and soil nutrient enrichment-and the sustainability of the milpa farming system in southern Belize. Milpa communities are part of the broader SES and therefore are affected by changes to it. Milpa communities can also be enabled and participate in solution-finding. The findings imply that increasing the use of agroecology practices in milpa communities is needed and that government involvement and action, particularly from agriculture extension services, can facilitate a more sustainable milpa farming system and therefore more food and livelihood security in milpa communities in Belize. 


\section{Keywords}

Agroecology, Socio-Ecological Systems, Extension, Belize, Milpa Farming, Food Security, Sustainability

\section{Introduction}

The sustainability of milpa agriculture, a traditional Mayan farming system in southern Belize, is uncertain. A milpa is a small-scale subsistence farming system of shifting cultivation (Downey, 2009; Nigh \& Diemont, 2013), which traditionally involves slash-and-burn or slash-and-mulch techniques (Johnston, 2003; Thurston 1997). The milpa is a significant aspect of Maya culture; Maya identity, ceremony, community, and livelihood are all rooted in the milpa (De Frece \& Poole, 2008; Falkowski, Chankin, Diemont, \& Pedian, 2019). For centuries, the milpa has been a sustainable agriculture system (Altieri \& Toledo, 2011; Benitez, Fornoni, Garcia-Barrios, \& López, 2014; Ford \& Nigh, 2016; Nigh \& Diemont, 2013) by allowing areas to regenerate, creating a mosaic of forest succession stages and crop diversity, and providing major food sources and livelihoods for Maya milpa farmers (Daniels, Painter, \& Southworth, 2008; Isakson, 2007; Mt. Pleasant, 2016; Shal, 2002).

The slash-and-burn aspect of milpa farming, however, has become less reliable and less sustainable in the last 50 years due to forest loss, soil degradation, climate change, population growth, land tenure, poverty, and other factors (De Frece \& Poole, 2008; Levasseur \& Olivier, 2000; Lozada, 2014; New Agriculturist, 2005; Shal, 2002; Steinberg, 1998). Due to this uncertainty, milpa farmers who exclusively practice slash-and-burn in Belize may be more vulnerable to livelihood and food insecurity (Lozada, 2014; Okumu, 2013). Food security is the ability to provide present and future generations with a reliable food supply; it considers multiple factors and depends upon reliable crop production while sustaining a healthy ecological balance in a farming system (ESRI, 2008; Food and Agriculture Organization of the United Nations [FAO], n.d.; Mazumdar, 2008; Rao, Waits, \& Neilsen, 2000).

The milpa practices of slash-and-mulch (versus slash-and-burn) and soil nutrient enrichment (nutrient cycling) may be more sustainable in Belize. Slash-and-mulch (i.e., cutting and mulching vegeta- tion on-site) involves shorter fallow periods and can restore soil nutrients and stabilize yields; soil nutrient enrichment involves farming inputs that improve the soil conditions for production (Johnston, 2003; Mkhize, 2016; Thurston, 1997). Both slash-and-mulch and soil nutrient cycling are agroecological practices. As a science, practice, and movement of producing food in a more sustainable way (Altieri \& Toledo, 2011), agroecology involves multidisciplinary factors and a participatory and action-oriented approach to sustainable and just food systems (Méndez, Bacon, \& Cohen, 2013; RiveraFerre, 2018; Wezel et al., 2009).

Promoting agroecological practices may be necessary to facilitate food and livelihood security in milpa communities. Agriculture extension, a government service in Belize, is in an effective position to enable an increase in agroecological practices in Maya milpa communities (Drexler, 2019). In Belize, extension officers can work within the cultural traditions of the milpa system to facilitate support for increased agroecological practices (e.g., slash-and-mulch) while including farmers as partners in the process. This study examines perceptions of agroecological practices from milpa farmers and agricultural extension officers in Belize using an SES framework. SES considers transdisciplinary factors and linkages, including social, economic, environmental, cultural, governance, and other factors in the agroecological system.

\section{Background and Literature Review}

\section{The Milpa Farming System in Belize}

A milpa is a small-scale traditional Maya farming system of shifting cultivation. It involves clearing areas of forest to plant primarily corn, beans, and squash on nutrient-rich soil (Emch, 2003; Mt. Pleasant, 2016) for subsistence and selling at local markets (Downey, 2009; Nigh \& Diemont, 2013). Milpa farmers traditionally use slash-and-burn and/or slash-and-mulch practices (Johnston, 2003; Thurston, 1997). As a polycrop practice, the milpa is a "diverse and complex agroecosystem that, given its ample diversification and adaptation to local conditions, provides an excellent model system for agroecology" (Benitez et al., 2014, p. 1). The crop diversity of the milpa system can sustainably 
"increase the agroecosystem's productive capacity and resilience" and can therefore promote food security and food sovereignty, the "right to healthy and culturally appropriate foods" (Falkowski et al., 2019, p. 396).

The milpa is a significant aspect of Maya culture and livelihood. In Belize, the milpa system meets most of a family's need for food, wood, and income (Emch, 2003; Levasseur \& Olivier, 2000). Traditional ecological knowledge of the milpa "is important to the cultural integrity of Maya communities and the ecological integrity of tropical [and subtropical] lowland ecosystems" (Falkowski et al., 2019, p. 400). The milpa has been a sustainable agriculture system; as a forest mosaic of disturbance, there is "long-term carbon sequestration and an increasingly fertile anthrosol and enriched woodland vegetation" (Nigh \& Diemont, 2013, p. 45). However, the milpa system is "not indefinitely resilient, particularly in an era of global economic and environmental change" (Lozada, 2014, p. 75).

Slash-and-burn. As a traditional milpa practice, the slash-and-burn aspect of milpa farming (clearing and burning small areas of forests for crop rotation each year) has been misunderstood as having large-scale impacts on forests. This practice has been sustainable for centuries and has only recently (in the last 50 years) begun to be unsustainable in combination with climate change, forest loss, soil degradation, population growth, and other factors (De Frece \& Poole, 2008; Levasseur \& Olivier, 2000; Lozada, 2014; New Agriculturist, 2005; Shal, 2002; Steinberg, 1998). The burning aspect of milpa farming reduces carbon stocks, and the intense heat during burning can destroy critical root and seed banks (Uhl, 1987). Also, the practice of burning means fewer nutrients are returned to the soil, water-holding and nutrient status declines, and "risks of accelerated erosion, water runoff, and crop failure in times of below normal rainfall" (Kidd \& Pimental, 2012, p. 112) dramatically increase. Degraded natural resources negatively affect the rural poor (John \& Firth, 2005), which "has major impacts [on] the ecology, economy, food security and public health of the [Belizean milpa] communities" (Chicas, Omine, \& Ford, 2016).

Slash-and-mulch. Slash-and-mulch, practiced by about half the milpa farmers in the Toledo District (Drexler, 2019), is a traditional milpa practice where vegetation is cut and left to decompose. Mulch practice has been found to be far more beneficial in tropical regions by restoring degraded soils, providing shorter fallow periods, stabilizing crop yields (Johnston, 2003; Mkhize, 2016; Thurston 1997), and having similar planting and harvest timing, although tillage may be slower compared to slash-and-burn (Erenstein, 2003).

There may be disadvantages to slash-andmulch practice, including a possible increase in snakes or animal vectors. Also, there may be a need for fertilization inputs in mulch systems, although that is debated in the literature. For example, one study states, "Fertilization is essential to obtain acceptable yields under fire-free land preparation" (Denich, Vlek, de Abreu Sá, Vielhauer, \& Lücke, 2005, p. 51), but the study suggests the increased yields will compensate for fertilizer costs. Another study finds that external fertilizer inputs (as well as weeds and runoff) were avoided with mulching, and "increased SOM [soil organic matter] and water holding capacity were also achieved" (Lozada, 2014, p. 62). In other studies, mulching was found to improve soil nutrients and regulate surface temperatures (thus improving moisture and germination) as well as other benefits for crop productivity (Johnston, 2003; Mkhize, 2016; Thurston 1997).

\section{Agroecological Practices in Belize}

In Belize, "mixed intercropping, organic nutrient recycling processes, crop rotations, and irrigation facilities" (Government of Belize [GOB], 2003, p. 53) help to decrease pressure on deforestation while simultaneously increasing domestic production. Other methods of agroecology in farming systems include polycultures, agroforestry, using native seeds, and "encouraging natural enemies of pests, and using composts and green manure to enhance soil organic matter thus improving soil biological activity and water retention capacity" (Altieri \& Toledo, 2011, p. 588). A diversified agroecological system promotes sustainability and resilience through biological interactions, soil fertility regeneration, crop productivity and protection, and recycling nutrients and energy on a farm rather than using external inputs (Altieri \& Toledo, 2011). 
Promoting agroecological practices can facilitate food security while maintaining the health of ecosystems (FAO, n.d.).

\section{Socio-ecological Systems (SES) in Belize}

This study uses an SES framework to examine perceptions of agroecological practices from milpa farmers and agricultural extension officers in southern Belize. SES considers multidisciplinary linkages, including social, economic, environmental, cultural, and other factors in the agroecological system. The SES framework is an effective lens through which to study the complex and multidisciplinary issue of sustainable agroecological practices in milpa communities.

An SES is a linked network where an impact on one part of the system-loss or degradation of soil, for example — can affect human systems such as food security and farmer livelihoods (Lal, 2008; Levasseur \& Olivier, 2000; Molnar \& Molnar, 2000). Understanding each factor, as well as how it functions in the "complex whole" (Koutsouris, 2008, p. 269), is important.

Milpa communities are part of the broader SES and therefore are affected by changes to it; they experience system impacts and can be more vulnerable to increasing resource loss and degradation (Drexler, 2017; Flint, 2015; Okumu, 2013; C. A. Young, 2008). For example, as milpas expand deeper into forests, the ecosystem on which milpa farmers depend for their basic needs is affected (Lozada, 2014). With resource loss, there are implications for food and livelihood insecurity for milpa communities. That said, as part of the broader SESs, milpa communities can also be enabled and participate in solution-finding.

Dr. Elinor Ostrom is widely considered to be the foremost researcher on SES. Ostrom's conceptual framework uses a multilevel and multiperspectival examination of SES (e.g., social, economic, political) drivers, interactions, and outcomes. Ostrom's framework also involves adaptive resource management, coordinating with multiple stakeholders, collective action, self-organizing, and bottom-up (community-based) application of resource planning and management (Olsson, Folke, \& Berkes, 2004; Ostrom, 2009; Parrott, Chion, Gonzalés, \& Latombe, 2012).
SES challenges associated with milpa farming system sustainability can be described as "wicked" problems. Wicked problems are difficult to solve and are often complex, multidimensional, dynamic, difficult to recognize and find causality for, and connected within other problems (Hanstedt, 2012; Rittel \& Webber, 1973). Systemic issues such as food security and agriculture sustainability necessitate inclusive and "wicked" approaches (i.e., community-based, multiperspectival, and flexible system frameworks) to address problems.

\section{Agriculture Extension in Belize}

In Belize and elsewhere, one of the most effective ways to promote an increase in sustainable agroecological practices is through agriculture extension services. Extension has a strong institutional expectation as a conduit of informing, educating, and facilitating best practices for farmers (Seevers \& Graham, 2012). Extension programs can build resilience in milpa systems through multidisciplinary capacity-building and farmer participation (Ministry of Agriculture, Fisheries, Forestry, the Environment, Sustainable Development and Immigration, Government of Belize [MAFFESDI], n.d.) using "site-specific technologies [which] should include intensified water management strategies, slash-andmulch technologies, grain-based intercropping and, agroforestry techniques to increase and stabilize yields" (Lozada, 2014, p. 81). To improve agroecological sustainability, extension can promote "more resilient farming systems and practices, as well as sound coordination, exchange of information, methodologies, and tools between experts and institutions" (FAO, 2010, para. 12). Also, extension can "generate better social and environmental benefits" (Tandon, 2014, p. 8) and facilitate resource sustainability, a more sustainable milpa farming system, and food and livelihood security in Belize (Benitezet al., 2014).

The director of extension in Belize stated that farmer field schools (FFS) are one of the most effective extension collaboration models used in Belize, providing "empowerment and facilitation for [farmers] to [learn how to] solve their own problems" (B. Esquivel, personal communication, September 26, 2017). FFS is a participatory approach conducted in the farming community to "increase 
agricultural production and improve livelihoods in a way that is adapted to local contexts" (FAO, 2015, para. 11). One officer explained that both extension officers and farmers work side by side to solve problems in real time; when a problem is found, everyone participates as partners, "adapts," and "finds a solution" (V. Kuk, personal communication, January 14, 2019).

\section{Applied Research Methods}

This qualitative study uses phenomenology and semistructured interviews to describe the common lived experience of milpa farming sustainability from the perceptions of milpa farmers and extension officers. Phenomenology recognizes patterns, categories, and themes that emerge from the data collected in interviews (Creswell, 2013; Gall, Gall,
\& Borg, 2007; Ravitch \& Carl, 2016). The American Public University System Institutional Review Board (IRB) approved all study protocols and interview questions; all interviews followed a voluntary and informed consent procedure.

\section{Setting of the Study}

Semistructured interviews were conducted of five milpa farmers and three extension officers in the Toledo District. Toledo District is the southernmost district in Belize; its population is nearly $50 \%$ Q'eqchi' (Kekchi) Maya, 20\% Mestizo, and 17\% Mopan Maya. There are also Garifuna, Creole, East Indian, and Mennonite populations (Statistical Institute of Belize [SIB], 2018). Farmers in two milpa villages in Toledo District, Pueblo Viejo and Indian Creek, were interviewed (Figure 1).

\section{Figure 1. Map of Belize Showing Study Sites}

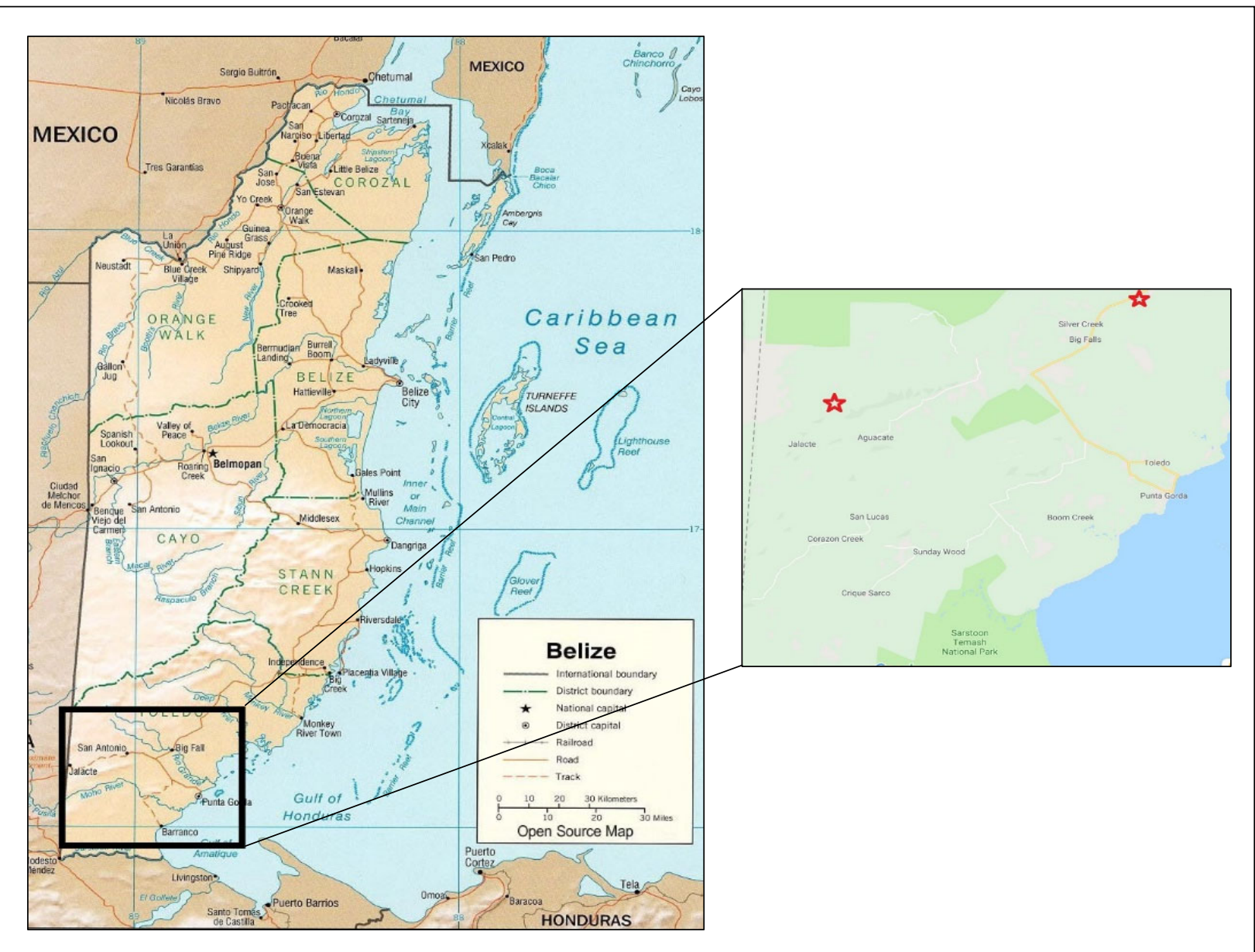

Sources: At Ease in Bellize Ltd., n.d.; Google Map of Pueblo Viejo (left) and Indian Creek (right) villages (2019). 
In milpa farming communities, households were selected using a stratified random design in each village. Sampling was purposive using the subpopulation of 'primary (head) milpa farmer' for each selected household. The subpopulation was intentional to elicit the perspective of farmers who have the most direct knowledge of local forests, soils, and agriculture systems. Two of the farmers randomly selected were Maya cultural and political leaders in their villages; they spoke to the importance of the milpa as part of their cultural practice. In-depth interviews of extension officers were also conducted in both office and field settings; three (of the four total) extension officers in the Toledo District in southern Belize were interviewed. Interviews for both groups included questions on the sustainability of farming practices and SES impacts in milpa farming communities.

\section{Data Analysis}

A series of open (analytical), axial (reduction and clustering of categories), and selective coding (the intersection or integration of categories) processes were used (Creswell, 2013; LeCompte, 2000; Pereira, 2007; Ravitch \& Carl, 2016; Strauss \& Corbin, 1994). The SES dynamics regarding sustainability in the slash-and-mulch and soil nutrient enrichment practices of traditional milpa farmers were examined. Emergent dominant themes were found to intersect with several multiperspectival SES indicators.

\section{Results}

Results from the qualitative approach include perception data from semistructured interviews of five milpa farmers and three extension officers. Two emergent thematic categories (codes) linked to the sustainability of the milpa farming system were identified: (1) Slash-and-mulch, and (2) soil nutrient enrichment practices. These agroecological practices were expressed by both milpa farmers and extension officers as having (a) economic, (b) environmental, and (c) cultural linkages to sustainable agroecological practices in milpa communities of southern Belize.

\section{Milpa Farmer Perspectives}

All milpa farmers interviewed for this study de- scribed their farming system as including slash-andburn farming. Some farmers also use slash-andmulch and soil enrichment practices. Slash-andmulch with no burning was considered by interview participants as a "new" farming technology, although mulching has been a traditional practice of milpa farming for centuries (Thurston, 1997). Slash-and-mulch milpa farming involves cutting trees and other vegetation for farm plots, but instead of burning the debris, farmers allow a decay or mulching process to occur. Mulching and soil enrichment were identified by extension officers and two farmers interviewed for this study as having a positive effect on soil and crop sustainability. Soil enrichment restores health and nutrients to the soil, which are primary needs for milpa farmers to increase productivity sustainably (Ong \& Kho, 2015). In the interviews, milpa farmers perceived environmental, economic, and cultural impacts of slash-and-mulch and soil nutrient enrichment practices in the SES.

Environmental perspectives. From an environmental perspective, milpa farmers traditionally cut trees and bushes (referred to locally as "chop bush") to plant on nutrient-rich "black" soil. Milpa farmers then choose to either burn the chopped debris (slash-and-burn) or leave it to decay (slashand-mulch). Two farmers interviewed for this study explained the use of fire and crop rotation: "I will soon start to chop bush, and then it dries, and then [I] burn it, and then plant it. You chop more bush to plant more [crops]." Milpa farmers interviewed for this study need to rotate on black soil due to the nutrient depletion in the soil over time. One farmer stated that they need soil enrichment assistance if they are to avoid cutting more forest. A farmer who already practices slash-and-mulch explained that he prefers the slash-and-mulch over burning:

... Not to burn it ... leave it there. Just leave it there, and it'll get rotten, right, and leave the stump right there, because the stump, it holds a lot of soil; when it's raining, it won't flush off. So, just leave the stump right there until it gets rotten.

Economic perspectives. From an economic 
perspective, slash-and-mulch and soil nutrient enrichment practices can improve the production and livelihoods of milpa farmers. To reduce costs, some farmers avoid fertilizers through crop rotation. One farmer explained why he rotates crops to use nutrient-rich black soil and how this is sustainable financially because black soil does not require fertilizer input. He explained they chop vegetation for the soil; otherwise, the soil gets too dry and hard, 'but, if we change every year, it doesn't need fertilizer. Yah, just normal planting-organic...That's why we maintain for [sic] we forest." One study, however, suggested that using fertilizers increases yields enough to more than compensate for fertilizer costs (Denich et al., 2005).

Soil enrichment involves fertilizer inputs (chemical or nonchemical); all farmers interviewed stated they buy and/or use fertilizer inputs. However, adding nonchemical enrichment can be low to no cost. One farmer explained that keeping forests intact is important for his village's economic development and tourism industry:

We understand the slash and burn is [bad]sometimes for humans, for us and also for a wildlife — and, so, we are trying to avoid that now. We are working very closely with the village leaders $\ldots$ because we need to take care of our forest, including creeks, rivers, and streams, and so forth.

Cultural perspectives. As part of the Maya culture and tradition, milpa farmers are taught by family how and when to plant and harvest milpa crops, usually related to rain and moon cycles. In this way, many aspects of the agroecological system are passed down from generation to generation. Some farmers were not interested in learning soil enrichment technology. One farmer stated: "Black soil is better [to farm]. I would chop because that's what, you know, works for [us] versus using the technology to put nutrients in the soil." One farmer described going further and further into the forest each year to farm. Two farmers were interested in learning new technologies and adapting their practice. For example, one farmer expressed being interested in effective microorganisms (EM) for soil enrichment:
It would be interesting to bring something with the soil and mix it up-and put plants there like tomatoes. You could plant when you mix up the soil... the [plants] come very good. And, with corn too... Yes, yes - that would be interesting ...interesting. You bring some soil, you just mix it up, and plant some there.

Another stated that exclusively using slashand-burn, a traditional form of agriculture in southern Belize Maya villages, is not culturally sustainable. He stated:

The only way we could damage [the milpa farming culture] for us is if we continue to slash and burn, and burn, and slash and burn — and, we believe that one day our crop will never come out good again because the fertile[ity] of the ground is washed off, so everything goes in the creeks, in the river; and, the land becomes poor and poor and poor and poor - and, so, now, we don't want to practice that because we understand the situation there. So, we believe that to maintain the soil, to treat the soil in a proper way...not to cut down the trees or not to burn it-even though if you want to fall something - but, leave it therejust, leave it there, and it'll get rotten.

Cultural factors are linked to economic and environmental factors. To some farmers, slash-andmulch can improve the sustainability of the agriculture system (i.e., increasing production, income, and resource sustainability).

\section{Extension Officer Perspectives}

The main mission of extension is to promote new agriculture practices, technologies, and innovations (Seevers \& Graham, 2012; U.S. Department of Agriculture, National Institute of Food and Agriculture [USDA NIFA], 2019); for southern Belize milpa communities, this includes slash-and-mulch and nutrient enrichment practices. Extension officers interviewed for this study commonly perceived slash-and-mulch farming and soil nutrient enrichment as beneficial to sustainable agroecology practices. Extension officers perceived the environmental, economic, and cultural effects of 
these two practices. However, extension officers recognized that there are institutional barriers, including lack of training in new technologies and lack of support from the central extension office. Currently, there are four extension staff responsible for a largely rural district of 52 communities.

Environmental perspectives. One extension officer interviewed for this study stated that mulching instead of burning is "climate-smart" because mulching keeps more moisture and nutrients in the soil, which benefits farmers, whereas burning would expose and heat up the soil, causing nutrient loss. Another officer explained the benefits of leaving the grasses to rot in the mulching process; the grass "covers the soil [and] ... there's a little moisture by the roots of the plant ... it will keep the soil cool instead of in the hot sun ... so it does work. It does work." He explained, "The advantage [of slash-and-mulch] is that it improves the soil fertility, but the disadvantage is that it's too bushy and people don't want to go in there ... because it attracts maybe snakes and other things." One extension officer explained that they "need to do a little bit more public awareness in terms of the negative effects [of burning]" due to air pollution, global warming, and other effects, and to show the proof that alternatives (i.e., mulching) work.

Regarding soil nutrient enrichment, extension officers commonly perceived that soil nutrient enrichment and ground cover could be beneficial for farmers. One extension officer interviewed was trying to educate and promote effective microorganisms (EM). He stated, "A lot of farmers, they are starting to use organic material-meaning chicken manure. They are using a lot of EM agriculture to build up the soil fertility." The same officer also explained the benefits of mucuna beans for nutrient enrichment:

We have some farmers that benefit from the training as well, because, at some point, we introduce some types of fertilizer that you incorporate in the soil ... [for example] mucuna beans: the Mennonites [presuming he means the less mechanized Amish community] use it a lot, you know; they don't use a lot of synthetic fertilizer, they only use these types of mucuna beans.
Another extension officer explained the benefits of arachis (Arachis glabrata), a wild peanut perennial. Arachis is useful for milpa farmers as an effective ground and soil cover and as a nitrogenfixing plant. Agroecological practices mimic or replicate the nutrient cycling in forest ecosystems while allowing for sustainable production of agriculture (Kidd \& Pimental, 2012); extension officers can promote nutrient cycling with increased slashand-mulch and adding fertility (soil nutrient enrichment) to reduce the need for forest clearing for black soil.

Economic perspectives. There are economic linkages to environmental and cultural factors in promoting sustainable agroecological practices in milpa communities. Extension officers need more support, technical training, and human resources allocated from the central extension office in the capital of Belmopan to prioritize sustainable agroecological practices. One officer noted, "We need support from them, because we cannot do it alone ... We need to prioritize [climate-smart] topics because everything now is climate change ...

Everything is focused around climate change and resilience." To cope with the low numbers of staff, extension officers interviewed for the study need to collaborate with other government agencies and nongovernmental organizations to carry out some aspects of their extension duties.

Cultural perspectives. When asked if the milpa farming system is sustainable, one extension officer answered "no" due to the lack of youth involvement. Another answered "yes" due to cultural traditions and knowledge passed down through generations. The same officer also stated the milpa system would only be sustainable if farmers adapt (i.e., stopped burning). He promoted slash-andmulch, where farmers "just have to chop and leave it into dry ... and they don't have to burn." An extension supervisor in Belmopan suggested that extension officers can work within the cultural traditions of the milpa system to promote effective technologies:

[We need] a way to demonstrate to [the farmer] a way to adequately compensate for what they are moving ... we need to look at injecting proportionate technology in the milpa 
system, and then look at how the farmers react to that injection. It's a learning process, not to challenge traditional [farming methods, but try to promote] a few [effective] agricultural practices like soil conservation, irrigation systems, and integrated pest management. (G. Ramirez, personal communications, September 26, 2017)

\section{Discussion}

There are positive system impacts from the agroecological practices of slash-and-mulch and soil nutrient enrichment on Maya milpa farming communities. Slash-and-mulch practice (leaving debris to decay on site) has the benefits of soil cover and adding nutrients to the soil. Soil enrichment practice can include adding chemical or nonchemical fertilizers (e.g., chicken manure, mucuna beans, arachis), and integrating effective microorganisms (EM) to break down slashed debris faster and build soil fertility. In interviews, both milpa farmers and agriculture extension officers perceived environmental, economic, and cultural linkages to agroeco- logical practices. Increasing these practices can enable farmers to achieve food and livelihood security in milpa communities of southern Belize.

Using SES theory, common themes and linkages were interwoven with slash-and-mulch and soil enrichment practices. Both agroecological practices were perceived by milpa farmers and extension officers as conduits for sustainable agriculture in southern Belize. Adapted from Ostrom's model, an SES map (Figure 2), using responses from this study, demonstrates the common themes, linkages, and intersections of environmental, economic, and cultural perceptions of the agroecological practices of slash-and-mulch and soil nutrient enrichment. Implications of increasing the agroecological practices of slash-and-mulch and soil nutrient enrichment practices could foster higher crop production with resource and culture sustainability in a sustainable SES; in turn, this is linked to food and livelihood security for milpa farmers in southern Belize.

The SES model (Figure 2) is intended to be a small picture of an otherwise larger and more com-

\section{Figure 2. A Variation of Ostrom's Socio-Ecological Systems Model, Adapted Using this Study's Perception Data on Environmental, Economic, and Cultural Linkages to Slash-and-Burn and Soil Enrichment Practices in the Milpa Farming System in Southern Belize}

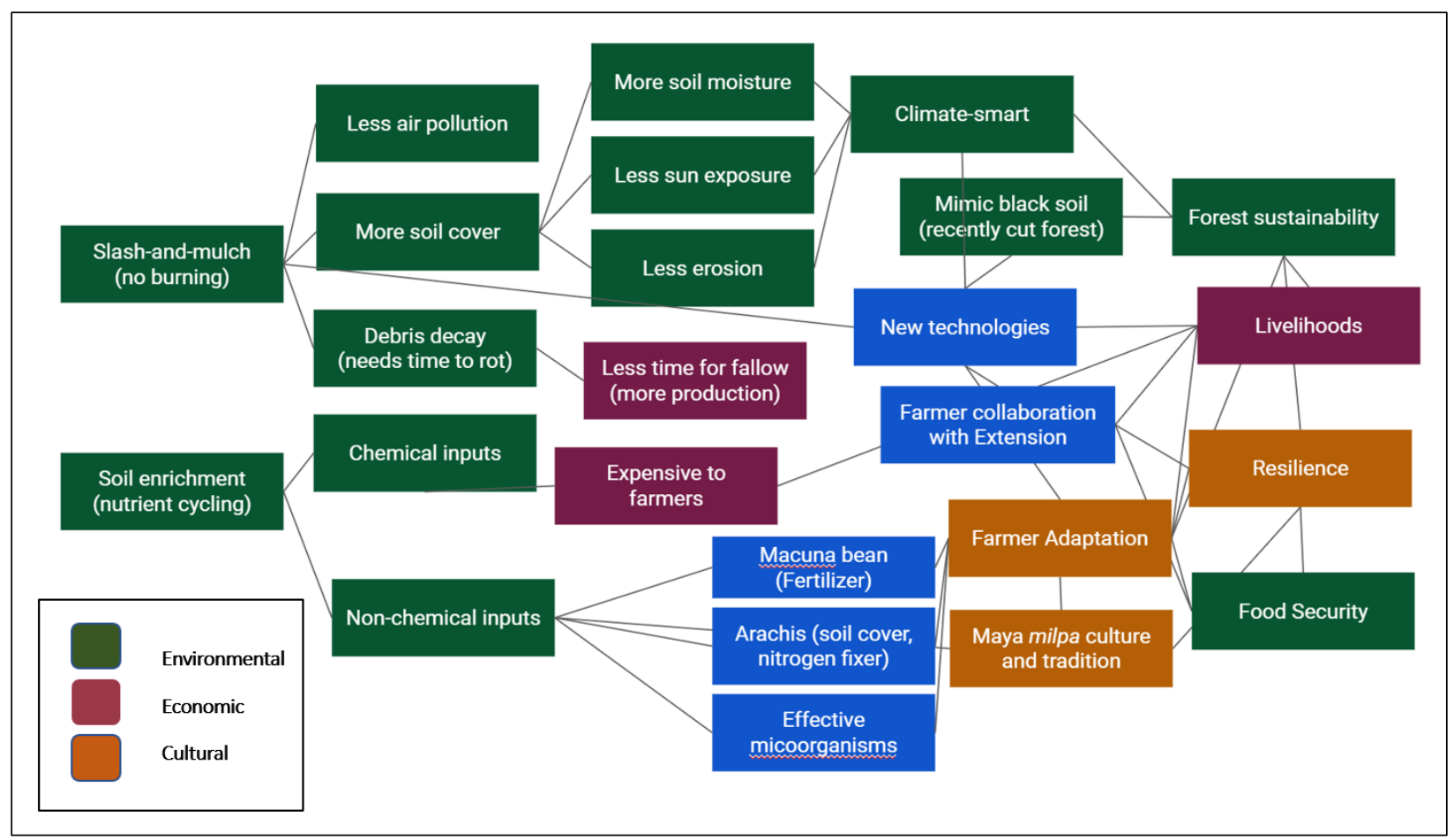


plex milpa agroecological system. Other SES linkages could be investigated, including factors such as forest and biodiversity sustainability, climate regulation, health and nutrition of families, inclusion of farmers as partners in the process, encouragement of youth farmers, collective action, stewardship, adaptation, and multiple other system factors.

Agriculture extension is an effective position to promote sustainable agroecological practices in southern Belize because it has a strong institutional expectation as a conduit of informing, educating, and demonstrating best practices for the public. One effective extension method in Belize is the Farmer Field School (Esquivel, 2017); working within milpa cultural traditions, extension can include milpa farmers as partners in the problemsolving process (Drexler, 2019). In this way, extension officers can promote agroecological practices-particularly, slash-and-mulch and soil nutrient enrichment—and address food and livelihood insecurities in milpa communities in southern Belize (Drexler, 2019).

\section{Conclusion}

There are positive SES effects from the agroecological practices of slash-and-mulch and soil nutrient enrichment on Maya milpa farming communities in southern Belize. Although slashand-burn milpa farming has been sustainably practiced for centuries, factors such as climate change, population growth (i.e., increased pressures on forests soils, and crop production), and poverty have made slash-and-burn less sustainable in the last half-century. Traditional milpa practices of slash- and-mulch and soil nutrient enrichment, however, are perceived to have positive environmental, economic, and cultural SES linkages. Extension officers can promote the increased adoption of the agroecological practices of slash-and-mulch and soil nutrient enrichment to benefit milpa farmers.

The findings of this study suggest that increasing the use of agroecology practices in milpa communities, specifically slash-and-mulch and soil nutrient enrichment, is needed. Further, increasing agroecology practices necessitates government involvement and action-particularly from agriculture extension - to facilitate a more sustainable milpa farming system. Therefore, extension and agroecological practices can positively affect food and livelihood security in milpa communities in Belize.

\section{Recommendations for Research and Practice} Future qualitative, quantitative, and mixed-method studies are recommended. Important recommendations for extension practice include (1) An increase in support for extension services promoting slashand-mulch and soil nutrient enrichment and other nonchemical technologies (e.g., effective microorganisms, mucuna beans); (2) An increase in extension using a more holistic and SES approach in promoting agroecology practices to include milpa farmers and village leaders as partners; and (3) An increase in farmer field schools (FFS) and youth involvement programs, working within milpa cultural traditions to include milpa farmers as partners in the problem-solving process.

\section{References}

Altieri, M. A., \& Toledo, V. M. (2011). The agroecological revolution in Latin America: Rescuing nature, ensuring food sovereignty and empowering peasants. Journal of Peasant Studies, 38(3), 587-612. https://doi.org/10.1080/03066150.2011.582947

At Ease in Bellize Ltd. (n.d.). Guide to Belize: Sights by district. Retrieved April 19, 2019, from http://www.guidetobelize.info/en sights.html

Benitez, M., Fornoni, J., Garcıa-Barrios, L., \& López, R. (2014). Dynamical networks in agroecology: The milpa as a model system. In M. Benítez, O. Miramontes, \& A. Valiente-Banuet (Eds.), Frontiers in ecology, evolution and complexity. Mexico City: CopIt-arXives.

Chicas, S. D., Omine, K., \& Ford, J. B. (2016). Identifying erosion hotspots and assessing communities' perspectives on the drivers, underlying causes and impacts of soil erosion in Toledo's Rio Grande Watershed: Belize. Applied Geography, 68, 57-67. https://doi.org/10.1016/j.apgeog.2015.11.010

Creswell, J. W. (2013). Qualitative inquiry and research design: Choosing among five approaches. SAGE Publications. 
Daniels, A. E., Painter, K., \& Southworth, J. (2008). Milpa imprint on the tropical dry forest landscape in Yucatan, Mexico: Remote sensing \& field measurement of edge vegetation. Agriculture, Ecosystems \& Environment, 123(4), 293304. https://doi.org/10.1016/j.agee.2007.07.003

Denich, M., Vlek, P. L., de Abreu Sá, T. D., Vielhauer, K., \& Lücke, W. (2005). A concept for the development of firefree fallow management in the Eastern Amazon, Brazil. Agriculture, ecosystems \& environment, 110(1-2), 43-58. https://doi.org/10.1016/j.agee.2005.05.005

Downey, S. S. (2009). Resilient networks and the historical ecology of $Q^{\prime}$ eqchi' Maya swidden agriculture (Doctoral dissertation). University of Arizona, Tucson. http://hdl.handle.net/10150/195686

Drexler, K. (2017). Summary of findings for survey-interviews of Red Bank village, March 20-23, 2017. Unpublished report.

Drexler, K. A. (2019). Extension leadership and sustainable agriculture in Belize forest farming communities: A socio-ecological systems approach (Doctoral dissertation). New Mexico State University, Las Cruces, New Mexico.

De Frece, A., \& Poole, N. (2008). Constructing livelihoods in rural Mexico: Milpa in Mayan culture. Journal of Peasant Studies, 35(2), 335-352. https://doi.org/10.1080/03066150802151090

Emch, M. (2003). The human ecology of Mayan cacao farming in Belize. Human Ecology, 31(1), 111-131. https://doi.org/10.1023/A:1022886208328

Erenstein, O. (2003). Smallholder conservation farming in the tropics and sub-tropics: A guide to the development and dissemination of mulching with crop residues and cover crops. Agriculture, Ecosystems \& Environment, 100(1), 17-37. https://doi.org/10.1016/S0167-8809(03)00150-6

ESRI. (2008). GIS for sustainable agriculture. Retrieved from http://www.esri.com/library/bestpractices/sustainable-agriculture.pdf

Falkowski, T. B., Chankin, A., Diemont, S. A., \& Pedian, R. W. (2019). More than just corn and calories: A comprehensive assessment of the yield and nutritional content of a traditional Lacandon Maya milpa. Food Security, 11(2), 389-404. https://doi.org/10.1007/s12571-019-00901-6

Flint, R. W. (2015). Belize pollution problems. Retrieved from the Sustainability Now For Belize, C.A., website, archived at https://web.archive.org/web/20160420132354/http://sustainability-now.org/belize-pollution-problems/

Food and Agricultural Organization of the United Nations (FAO). (n.d.). The 10 elements of agroecology guiding the transition to sustainable food and agriculture systems. Retrieved from http://www.fao.org/3/i9037en/i9037en.pdf

Food and Agricultural Organization of the United Nations (FAO). (2010). Brief profile of the agriculture sector (Belize). Retrieved from http://www.fao.org/climatechange/download/28928-0e0bc49fd6e72690e82c4c3b9d4dc6f52.pdf

Food and Agricultural Organization of the United Nations (FAO). (2015). Farmer field schools: A participatory approach to capacity building for efficient, sustainable and inclusive food production systems. Retrieved from http://www.fao.org/africa/news/detail-news/en/c/358283/

Ford, A. \& Nigh, R. (2016). The Maya forest garden: Eight millennia of sustainable cultivation of the tropical woodlands. London \& New York: Routledge. https://doi.org/10.4324/9781315417936

Gall, M. D., Gall, J. P., \& Borg, W. R. (2007). Educational research: An introduction (8 ${ }^{\text {th }}$ Edition). Boston, Massachusetts: Pearson.

Government of Belize (GOB). (2003). The national food and agriculture policy (2002-2020): No farmer=no food. Ministry of Agriculture and Fisheries. Retrieved from http://agriculture.gov.bz/wp-content/uploads/2017/05/Policy-Document1.pdf

Hanstedt, P. (2012). General education essentials: A guide for college faculty. San Francisco: John Wiley \& Sons.

Isakson, S. R. (2007). Between the market and the milpa: Market engagements, peasant livelihood strategies, and the on-farm conservation of crop genetic diversity in the Guatemalan highlands (Doctoral dissertation). University of Massachusetts Amherst. Available from Proquest, AAI3289202.

John, L., \& Firth, D. (2005). Water, watersheds, forests and poverty reduction: A Caribbean perspective. International Forestry Review, 7(4), 311-319. https://doi.org/10.1505/ifor.2005.7.4.311

Johnston, K. J. (2003). The intensification of pre-industrial cereal agriculture in the tropics: Boserup, cultivation lengthening, and the Classic Maya. Journal of Anthropological Archaeology, 22(2), 126-161.

https://doi.org/10.1016/S0278-4165(03)00013-8 
Kidd, C. V., \& Pimental, D. (Eds.). (2012). Integrated resource management: Agroforestry for development. San Diego, California: Elsevier.

Koutsouris, A. (2008). Higher education facing sustainability: The case of agronomy. International Journal of Learning: Annual Review, 15(4), 269-276. https://doi.org/10.18848/1447-9494/CGP/v15i04

Lal, R. (2008). Soils and sustainable agriculture: A review. Agronomy for Sustainable Development, 28(1), 57-64. https://doi.org/10.1051/agro:2007025

LeCompte, M. D. (2000). Analyzing qualitative data. Theory into Practice, 39(3), 146-154. https://doi.org/10.1207/s15430421tip3903 5

Levasseur, V., \& Olivier, A. (2000). The farming system and traditional agroforestry systems in the Maya community of San Jose, Belize. Agroforestry Systems, 49(3), 275-288. https://doi.org/10.1023/A:1006327403980

Lozada, S. B. (2014). Securing food and livelihoods: opportunities and constraints to sustainably enhancing household food production in Santa Familia Village, Belize (Master's thesis). University of Montana, Missoula. Retrieved from https://scholarworks.umt.edu/etd/4202/

Mazumdar, S. (2008). Geographic information systems in the application of precision agriculture for sustainable sugarcane production in the Republic of Panama. (Master's thesis). McGill University, Montreal, Quebec. https://escholarship.mcgill.ca/concern/theses/6q182n86q

Méndez, V. E., Bacon, C. M., \& Cohen, R. (2013). Agroecology as a transdisciplinary, participatory, and action-oriented approach. Agroecology and Sustainable Food Systems, 37(1), 3-18. https://doi.org/10.1080/10440046.2012.736926

Ministry of Agriculture, Fisheries, Forestry, the Environment, Sustainable Development and Immigration, Government of Belize (MAFFESDI). (n.d.). Extension. Retrieved February 20, 2019, from http://www.agriculture.gov.bz/extension-2/

Mkhize, T. (2016). Exploring farming systems and the role of agroecology in improving food security, productivity and market access for smallholder farmers (Master's thesis). University of KwaZulu-Natal. https://www.semanticscholar.org/paper/Exploring-farming-systems-and-the-role-of-in-foodMkhize/604b87d6944593d6bc9eef5fe3cce70c43a4ab73

Molnar, S., \& Molnar, I. M. (2000). Environmental change and human survival. Upper Saddle River, New Jersey: Prentice Hall.

Mt. Pleasant, J. (2016). Food yields and nutrient analyses of the Three Sisters: A Haudenosaunee cropping system. Ethnobiology Letters, 7(1), 87-98. https://doi.org/10.14237/ebl.7.1.2016.721

Nigh, R. \& Diemont, S. A. (2013). The Maya milpa: Fire and the legacy of living soil. Frontiers in Ecology and the Environment, 11(1), 45-54. https://doi.org/10.1890/120344

New Agriculturist. (2005). Country profile-Belize. Retrieved from http://www.new-ag.info/en/country/profile.php?a=847

Okumu, O. F. (2013). Small-scale farmers' perceptions and adaptation measures to climate change in Kitui County, Kenya (Master's thesis). University of Nairobi, Kenya.

Olsson, P., Folke, C., \& Berkes, F. (2004). Adaptive co-management for building resilience in social-ecological systems. Environmental Management, 34(1), 75-90. https://doi.org/10.1007/s00267-003-0101-7

Ong, C. K., \& Kho, R. M. (2015). A framework for quantifying the various effects of tree-crop interactions. In C. K. Ong, C. R. Black, \& J. Wilson (Eds.), Tree-crop interactions, 2nd edition: Agroforestry in a changing climate (pp. 1-23). CABI International. https://doi.org/10.1079/9781780645117.0001

Ostrom, E. (2009). A general framework for analyzing sustainability of social-ecological systems. Science, 325(5939), 419422. https://doi.org/10.1126/science.1172133

Parrott, L., Chion, C., Gonzalès, R., \& Latombe, G. (2012). Agents, individuals, and networks: Modeling methods to inform natural resource management in regional landscapes. Ecology and Society, 17(3). https://doi.org/10.5751/ES-04936-170332

Pereira, L. (2007). Developing perspectival understanding. In P. C. Taylor \& J. Wallace (Eds.), Contemporary qualitative research: Exemplars for science and mathematics educators (pp. 189-203). Dordrect, Netherlands: Springer https://doi.org/10.1007/978-1-4020-5920-9 17 
Rao, M., Waits, D., \& Neilsen, M. (2000). A GIS-based modeling approach for implementation of sustainable farm management practices. Environmental Modelling and Software, 15(8), 745-53. https://doi.org/10.1016/S1364-8152(00)00032-3

Ravitch, S. M., \& Carl, N. M. (2016). Qualitative research: Bridging the conceptual, theoretical, and methodological. SAGE Publications.

Rivera-Ferre, M. G. (2018). The resignification process of agroecology: Competing narratives from governments, civil society and intergovernmental organizations. Agroecology and Sustainable Food Systems, 42(6), 666-685. https://doi.org/10.1080/21683565.2018.1437498

Rittel, H. W., \& Webber, M. M. (1973). Dilemmas in a general theory of planning. Policy Sciences, 4(2), $155-169$. https://doi.org/10.1007/BF01405730

Seevers, B., \& Graham, D. (2012). Education through cooperative extension (3rd ed.). University of Arkansas Press.

Shal, V. (2002). The Mayas and their land (Report No. 489). Belize Development Trust. Retrieved from https://ambergriscaye.com/BzLibrary/trust489.html

Statistical Institute of Belize (SIB) (2018). Postcensal estimates by administrative area and sex (2010-2018). Retrieved from http://www.sib.org.bz/statistics/population

Steinberg, M. K. (1998). Political ecology and cultural change: Impacts on swidden-fallow agroforestry practices among the Mopan Maya in southern Belize. The Professional Geographer, 50(4), 407-417. https://doi.org/10.1111/0033-0124.00129

Strauss, A., \& Corbin, J. (1994). Grounded theory methodology. In N. K. Denzin \& Y. S. Lincoln (Eds.), Handbook of Qualitative Research (pp. 273-285). Thousand Oaks, California. SAGE.

Tandon, N. (2014). Strengthening sustainable agriculture in the Caribbean (Report for the FAO). Washington, D.C.: Multilateral Investment Fund. Retrieved from https://competecaribbean.org/wpcontent/uploads/2015/02/Strengthening Sustainable Agriculture in-the-Caribbean web.pdf

Thurston, H. D. (1997). Slash/mulch systems: Sustainable methods for tropical agriculture. Boulder, Colorado: Westview.

Uhl, C. (1987). Factors controlling succession following slash-and-burn agriculture in Amazonia. Journal of Ecology, 75(2), 377-407. https://doi.org/10.2307/2260425

U.S. Department of Agriculture, National Institute of Food and Agriculture (USDA NIFA). (2019). Joint Cooperative Extension Programs at 1862 Land-Grant Institutions and University of the District of Columbia Public Postsecondary Education Reorganization Act Program. U.S. Department of Agriculture. Retrieved from https://nifa.usda.gov/sites/default/files/program/2020-Smith-Lever-UDC-Joint-2aug19.pdf

Wezel, A., Bellon, S., Doré, T., Francis, C., Vallod, D., \& David, C. (2009). Agroecology as a science, a movement and a practice. A review. Agronomy for Sustainable Development, 29(4), 503-515. https://doi.org/10.1051/agro/2009004

Young, C. A. (2008). Belize ecosystems: Threats and challenges to conservation in Belize. Conservation Letter. Tropical Conservation Science, 1(1), 18-33. Retrieved from https://tropicalconservationscience.org 